\title{
THE RETABLOS MAYORES OF THE CANTUÑA CHAPEL OF SAN FRANCISCO IN QUITO, ECUADOR
}

\author{
MARY GRIZZARD
}

The founding of the Franciscan missionary efforts in 16th century Quito, Ecuador, stemmed from their administrative center in Lima. The latter was the original center of the Franciscans in all of Spanish South America, and was the ordinary residence of the Commissary General of Peru, whose jurisdiction encompassed all the Spanish possessions from Panama to the Straits of Magellan. It is to be noted that the Franciscan missionary endeavor was entitled the Santa Provincia de los Doce Apóstoles de Perú de la Orden de San Francisco.

This title is apparent, for instance, in the first page of the Crónica Franciscana de las provincias del Peri by Fray Diego de Córdova Salinas in the 17 th century. It is indeed the only general Spanish colonial history of Franciscan efforts in that vast territory. Accordingly, as a contemporary Franciscan source, Córdova's history gives a more accurate sense of their experience than that generally found in modern histories.

According to Córdova, the first convento or friary of the Order in this Holy Province of 12 Apostles was founded in the city of San Francisco de Quito in 1535. The convento itself was named after the Apostle St. Paul, because it was founded on his feast day, on the 25th of January, in 1535, some months after settlement had begun in the city. The city itself had been formally founded the year before. Donations made by pious conquerors of the region provided the funds for the construction of the convento.

The convento was founded two blocks from the Plaza Mayor, in the place where the most prestigious captains of the Inca ruling class had lived. The founder was Fray Jodoco Ricke, from Ghent, who had arrived in 1532, with Fray Juan de Granada, the Commissary General of Española.

Córdova's history continues, saying that there were so many indians who came to Quito to hear the Christian Doctrine that they left whole towns deserted, and many of them moved into Quito. The Franciscan 
convento of Quito also had the honor of having the first baptismal font in the Province.

And here during the early missionary period the fable of the treasure of Cantuna was supposed to have taken place. According to legend, the indian Cantuna was the son of one of Atahualpa's Inca generals. Cantuna had been orphaned and badly deformed in an accident. Nevertheless, he was adopted by a Spaniard, Captain Hernán Juárez, who taught him to read and write, and converted him to Christianity. Since Cantuna had access to a hidden treasure of Inca gold, this was passed to the Franciscan church. This curious legend has been repeated many times. The late Dominican father Vargas reprinted the legend in his Patrimonio Artistico Ecuatoriano of 1967. He in turn obtained it from Padre Compte's Varones Ilustres de la Orden Seráfica en el Ecuador, who in turn had learned of it from Padre Juan Velasco's Historia Moderna del Reino de Quito. No one, including Padre Velasco, ever gave credence to the story. Neverthless, since so many people continued to believe the legend, it was for this reason that the chapel, contiguous to the main Franciscan church, became known as La Cantuna. In the 16th century, it was originally the indians' own chapel, dedicated to the Dolores de la Santísima Virgen. By the second half of the 17 th century, during what was apparently a remodeling of this chapel, several confraternities had added side retablos of their own, and the chapel had passed to general use. It is interesting that there may well have been some such person named Cantuna, but the burial records in the Franciscan cloisters indicate that a Francisco Cantuña was interred in 1669. This burial, some hundred years after the likely period of the indian Cantuna's death, may represent the following possibilities: a reburial of the 16 th century indian, the burial of a descendant, a mistake in the inscription, or actually a close concordance with the date of the remodeling of this chapel probably in the 1660 s.

Besides being the center of great missionary activity, the convento was the center of learning, where music, art, and writing were taught. It was also the seat of considerable sophistication in the exegesis of sacred letters. According to Córdoba, there were usually on hand 6 readers of Theology, Logic, and Philosophy, who used an extensive reference library belonging to the Order. It was this notice in Córdoba's history that caused me to look carefully at some of the titles held, and to probe their contents with the undertanding that there was a truly active interest in their ideas within the convento itself. 
Accordingly, the medieval ideas of apocalyptic mission and the Franciscans in Quito are seen in several texts in their library, and are reflected in the imagery of the high altar. The Franciscan missionaries everywhere, as well as in Ecuador, inherited a rich eschatological tradition, expressed in a spirit of apocalyptic conversion. Remember that it was termed the Holy Province of 12 Apostles. There was correspondingly an idea current for several centuries among Franciscans that their mission was analogous to that of the 12 Apostles. It was an important symbol to the Franciscan mentality. Accordingly, they believed themselves to be the divinely inspired elect whose role was the renovatio of the evengelical life in the last age of the world.

Although Spanish American Franciscan libraries have not been adequately surveyed for their holdings, it is intriguing that these 16th century Franciscans brought with them to Quito a number of Joachite or prophetic texts. Although copies of Joachim of Fiore's 13th century text are indeed rare, volumes of the Liber de Cordord et veteris Testamen. ii do survive in Spain, and there are also copies of the papal prophecies called the Liber de Summis Pontificibus. In Quito itself, there are numerous compilations of prophetic texts in this category.

These prophetic texts draw upon Abbot Joachim of Fiore's scheme, that the transition to the last phase of history would include an intense missionary effort to convert all non believers to the faith. Based on the 12 Apostles of the previous age, a symbolic group of 12 religious would lead history toward the expected future. Similarly, in a 13th century book by Gerardo de Borgo San Donnino called Introduction to the Everlasting Evangelism, the role of the Franciscan missionaries is compared to the life and works of Jesus Christ. The appearance of Sts. Francis and Dominic began a new stage, like that of a Pentecost, towards the salvation of the world. There were also several other major medieval texts, in this vein of Franciscan thinking, including one of the 14th century, the Book on the Similarities of the Life of St. Francis and that of Our Lord, by Fray Bartolome of Pisa.

Although some of Joachim's, Gerardo's, and Bartolome's own ideas became altered and debased when other strains of apocalyptic thought were added, their influence, and especially the peculiar language of the Joachite scheme are recognizable in several texts in the Quito holdings. For instance, there is the 16th century reprint of Expositio superregulam, a 13th century commentary on the Franciscan rule by the Joachimist Peter Olivi. Similar ideas circulate through the writing of 
the disciple Ubertino da Casala, in his Arbor vitae crucifixae Iesu. There are copies of these specifically Joachimist texts in Quito's holdings.

The high altar is a plastic interpretation of Franciscan thought in the 16 th century. On the sides and on the base there are relief sculptures of the seated figures of the 4 Evangelists. The columns framing the presbytery support representations of the Virtues. In the intercolumniations, are the 12 Apostles. Above the Sagrario niche, in the center, is the Inmaculada by Bernardo Legarda. And above that, the Baptismal Group by Diego de Robles. It is not difficult to deduce the thinking that informed the structure of the retablo. On the foundation of the Gospels by the four Evangelists, the message of salvation was brought forward by the 12 Apostles. The message of salvation is in turn centered on Christ and Mary of the Immaculate Conception, all of which flowers into Christian Virtues. This was exactly the same as the Catechism taught by the Colegio de San Andrés, the teaching arm of the Convento of San Francisco. The pinnacle represents the mystery of the Trinity, centered above the Baptism (parenthetically of new souls as well); with the outermost flanking figures of the Virtues, the entire retablo refers to the predicted peace of the last age of the world brought about by the preaching of the Franciscan doctrine.

Over the course of time, there have been some alterations in the placement of images. The 18th century Inmaculada by Legarda replaces an earlier one described in a 1647 document. Legarda's Inmaculada was made in 1734, and although patterned after a canvas by Miguel de Santiago (one of these is in the Sala Capitular of San Agustín), Legarda's was the prototype and model in sculpture of all the similar replicas in Quito, which are called "Inmaculadas Legardianas".

The structure of the late 16th century retablo mayor of San Francisco is multilevel, with curving entablatures, supported by composite order columns and estipites. The elements, structure and massing are comparable to several retablos in Seville and its province during the same period.

The architect of the retablo mayor was likely Fray Francisco Benítez. He is identified as the Maestro Mayor of San Francisco at some time during the last years of the 16th century, and is accordingly attributed the choir stalls, the original mudéjar ceiling, the high altar, the Sala de Profundis, sacristy, library, and refectory. It would be more satisfactory to have the primary document, for this is secondary material as cited by Padre Compte, in his book Varones ilustres de la 
Orden Seráfica en el Ecuador. The timing of his work at San Francisco is verified to the extent that there is in the archives and early 17 th century document, dated 1627 , which identifies Padre Benítez as then 65 years old, and the Maestro Mayor.

If the retablo mayor is such an excellent example of a 16th century visualization of Franciscan thought, and uses such up-to-date building components, then one might expect that the Cantuña retablo mayor might be similarly current in its content and style, with particular reference to ideas embodied in texts in the convento holdings.

Stylistically, the 18th century high altar of the Cantuna Ghapel is fundamentally similar to the other retablos mayores of the period in the region, such as those of the Compañía, La Merced, and el Carmen Moderno, in the sense that they all respect the horizontal lines of the base, and the entablatures are not broken by the vertical lines of the columns, with base and capital generally Corinthian. Though they are all Baroque altars, they maintain a respect for the classical and the architectonic. Here on the Cantuna altarpiece, the spirals of the column shafts are covered with flowers and grape leaves. Generally speaking, they follow the recommendations of Vignola, who suggested that there should not be more than 6 spiral twists. That this advice was often followed in the region, is suggested by the similar column profile in the facade of La Compañia in Quito, as well as in the portal of the church of Carmen of San José de Cuenca. Generally speaking, this type of column is frequently used on retablos in the interior of churches. It was continued as a prominent feature of the Baroque in Ecuador.

We know that the chapel itself existed at least by the late 17 th century. According to a book of accounts of the Franciscan Order, the construction of the chapel was begun in the 1660s by Padre Manuel Almeida, who also built the 4 domes of the main cloister, and the dome of the second cloister (which is the museum today). There were several side altars in the Cantuña Chapel.

One, dedicated to San Lucas, had been sculpted by Padre Carlos in 1668, which was retouched on two occasions by Bernardo Legarda. According to the book of accounts, in 1731, he restored the retablo for the first time, and was also made an official of the Fiesta of San Lucas. There is an inscription on the St. Luke retablo which reads as follows: "In 1668 this image of St. Luke the Evangelist was finished, and Padre Carlos made it, and Bernardo de Legarda restored it in the 
year 1762 at his own expense". As a sculptor, Legarda was also a member of the confraternity of St. Luke.

As this voluntary repair of the St. Luke Altar, as well as other aspects of Legarda's life would suggest, he was strongly attached to San Francisco.

His nephew, Fray Mariano Legarda, was a Franciscan friar in this convento. Throughout most of Bernardo Legarda's life he was a single man. Although a statement in his death notice would have us believe that he never married, archival records do indicate that he married young to Alejandra Velázquez, whom he abandoned, having said she was unfaithful. He lived in the shadow of the church, and even purchased his houlsehold water supply from the friars. At his death he had as tenants in his house a painter and a carpenter, probably members of the Legarda atelier.

His brother Juan Manuel Legarda was an artist, and together the brothers Legarda had a thriving business of art and artisanry. Archival records indicate they made organs, retablos, frames, prints; sculpted figures, and painted canvases. Their customers ranged from oidores, to priests, friars, and several conventos in Quito.

Although there is no archival record to date which documents that Bernardo Legarda did sculpt the retablo of the high altar of Cantuna Chapel, there is circumstantial and stylistic evidence which would tend to suggest this to be the case. There has long been agreement that the Calvario group be attibuted to him. This agreement is on the part of the late Father José Vargas as well as José Navarro, both Ecuadoreans, writing between 1929 and 1985 on this subject. One certainly concurs with this attribution, given the similarities in proportion, graceful gestures and delicate physiognomy with Legarda's other works, especially the well-documented Inmaculada of 1734. Also, there is the suggestive evidence of his having earlier worked in the main church as well as in the Cantuna Chapel. Besides the Calvario itself, he may have done the entire retablo. He is documented as having wrought the entire high altar of La Merced in 1748-51. Also, numerous details such as the angel heads which appear on the column shafts, are in keeping with the porcelain-like delicacy of his other creations. He was a member of the Confraternity of St. Luke, which had a retablo in this same chapel, and he was apparently also a pious man. He had given freely of his work to the repair of his Confraternity's altarpiece. In his will he had also stated that he wanted to be buried in San Francisco Church itself, "in the vault of the altar of the In. 
maculada". In short, he lived in the shadow of the church, was buried within it, and executed at least two documented, important works for the church. He is known to have had a thriving atelier which produced sculpted figures, engraved mirrors, frames, retablos, and the like. And, certainly, the elegant, graceful figures of the Calvario, as well as details of the decoration, match the style of his documented work.

Only, however, if the documentation is found, may it truly be settled that he produced the entire retablo mayor in this chapel. The retablo certainly suggests the sensitivity of a pious person, working for devout, contemplative patrons.

And finally, the aforementioned interest in the texts and ideas of the Franciscans with their artwork should also be considered in this retablo. While the composition of the Calvario itself is not unusual and is similar to many others throughout Europe and the Americas, it does certainly accord with a series of Tridentine decrees of the Church, that artists produce clear, direct images, designed to inspire the faithful to pious contemplation. In addition, in the 16 th century as well as in 1759,1776 , and 1768 , well after the probable date of this altar (about 1735-40), the Chapel is recorded under the dedication of Our Lady of Sorrows. Here, the Lady of Sorrows is shown in context at the Crucifixion. The Trinity is read vertically in the altarpiece, from top to bottom: God, Spirit, and Son. One does not have to be reminded of the importance to the Franciscans of the Cruxifixion as a theme. In St. Francis' own life, the Crucifax at San Damiano spoke to him in a vision; in ecstacy he conversed with Christ, and in ecstasy he received the Stigmata, Christ's wounds imprinted on his own body. The Crucifixion was traditionally an object of special veneration by the Franciscans. This is repeated throughout their texts on hand in the convento itself, including the aforementioned Abor vitae Crucifixae lesu, the Summa llama sylva y practica del foro interior, utilissima para confessores y penitentes, by Fray Alonso de la Vega (Alcalá, 1594); and the Exercicios espirituales de las excelencias, provecho y necesidad de la oración mental (by Fray Antonio de Molina, with editions from Burgos of 1615 and 1686). These works all have in common contemplation of and identification with the experience of the crucified Christ. Therefore the simple exposition of the Calvario at eye level, with extremely veritist figures, attributed to Legarda, facilitate the spiritual devotions and even ecstatic concentration so desired by the Franciscans. 
In general this has been a survey of what is known about the Cantuña Altar, plus the confirmation of some of my archival findings on Legarda which further suggest his authorship. With the simple classicizing models for retablos which were readily available, such as the Andre dal Pozzo designs for the lateral altars in St. Ignatius in Rome, and later used in the Companía in Quito, as well as several other resources, there was a general drive in Ecuador toward the simplification and clarity of the retablo during the 18th century.

Finally, the more we understand the actual texts which were studied and discussed in particular locales, we have better access to the thinking of certain times and places in the past. Also with this understanding, the more certain few pieces of artwork especially appear to be highly successful visual distillations of these ideas.

\section{REFERENCES}

Crónica Franciscana de las provincias del Peri, by Fray Diego de Córdova Salinas. Lima, 1651.

Patrimonio Artístico Ecuatoriano, by Fray José María Vargas. Quito, 1967.

Varones ilustres de la orden seráfica en el Ecuador, by Padre Francisco María Compte. Quito, 1883.

And the specific holdings in San Francisco de Quito, as referenced in the text. 